\title{
INFANCIA, VISIÓN Y MELANCOLÍA EN LOS CUENTOS DE SILVINA OCAMPO
}

\author{
POR \\ SOPHIE DufaYs \\ Université Catholique de Louvain
}

No deja de llamar la atención el que, en los cuentos de Silvina Ocampo y, sobre todo, en su primera colección publicada en 1937: Viaje olvidado, el narrador adopte con frecuencia el punto de vista de un niño, cuya visión suele ser restringida y cuya percepción resulta en consecuencia fragmentaria. Incluso en la ausencia de un obstáculo físico a la mirada, la escasa experiencia del niño opera como una pantalla que reduce la comprensión. En el presente artículo, me propongo analizar las condiciones, los poderes y los efectos que tienen esta visión "infantil" y la visión en general en los cuentos de la escritora argentina. ${ }^{1} \mathrm{Mi}$ hipótesis es que la perspectiva estética de Ocampo, que se sostiene en esta visión, revela (y quizá nazca de) una concepción ontológica melancólica, y me pregunto si dicha concepción no influye en la valoración que recibe su obra por parte de la crítica académica desde los noventa. ${ }^{2}$ En efecto, en los estudios estéticos en general se observa que la noción de melancolía goza de un renovado éxito, auspiciado tanto por el psicoanálisis como por su prestigio cultural. ${ }^{3}$

1 Como Fiona J. Mackintosh, que ha dedicado un libro al tema y la perspectiva de la infancia en las obras de Silvina Ocampo y Alejandra Pizarnik, considero que "an understanding of their attitudes to childhood is fundamental to appreciating fully their work"; ver la presentación del libro.

2 La obra de Silvina Ocampo que permaneció relativamente discreta durante su vida fue (re)descubierta por la crítica después de su muerte en 1993. Desde finales de los años 90, ha dado lugar a varias tesis (sobre todo en Francia) y a numerosos estudios de dimensiones variadas que ponen en evidencia su riqueza y suelen insistir en su arte de la ambigüedad.

3 Ver por ejemplo Juliana Schiesari quien, en The Gendering of Melancholia, constata que la melancolía constituye actualmente un modo prevalente de autodefinición intelectual dentro de la elite cultural occidental y recuerda que dicha autodefinición se inscribe en una larga tradición inaugurada en el Renacimiento (italiano), a partir de un texto atribuido a Aristóteles (Problema XXX), Gendering, 2. Como ejemplo de la revaloración contemporánea de la melancolía (y del descrédito paralelo de la nostalgia), véase el artículo de Walter Moser. 


\section{PERCEPCIÓN Y MEMORIA DE LA INFANCIA}

Un primer efecto de la restricción de la visión en los cuentos de Ocampo es que refuerza el papel de los otros sentidos, en particular el del oído. En "Cielo de claraboyas" (primer cuento de Viaje olvidado) por ejemplo, donde una niña percibe el evento narrativo (el asesinato de otra niña) desde el cuarto de abajo y a través de vidrios borrosos, la omnipresencia del campo semántico del oído destaca aún más la limitación de la vista. Los sonidos, caracterizados por comparaciones, metáforas, verbos concretos, son materializados - "había voces que rebotaban como pelotas" (11), "una risa y otra risa caían de los pies desnudos" (11) - y la voz se vuelve metonímica de la persona o recibe sus atributos por hipálage -"No había nadie ese día en la casa de arriba, salvo el llanto pequeño de una chica" (11)- cuando no aparece como una persona -“Una voz de cejas fruncidas y de pelo de alambre" (11), "La voz de los pies embotinados crecía" (11-12), "brotaban gritos de pelo tironeado" (12), "surgió una risa de pelo suelto" (12), "y la voz negra gritó" (12)-. Las palabras, en medio de los sonidos percibidos, no gozan de su privilegio literario habitual sino que constituyen un sistema de signos entre otros, ni más ni menos expresivo que cualquier ruido, que los vestidos, los gestos o las miradas. Se ponen en escena como un material que tiene efectos físicos. ${ }^{5} \mathrm{La}$ voz recibe así un poder de visualización propiamente cinematográfico: "hay voces que se ven y que siguen revelando la expresión de un rostro cuando éste ha perdido su belleza", en "Autobiografía de Irene", 1: 154).

En los cuentos de Viaje olvidado los obstáculos a la visión son estrategias de escritura que intentan recrear la percepción de un(a) niño/a -su imaginación frente a lo desconocido- a la vez que ofrecen un enfoque particular de los recuerdos de infancia. La obstrucción de la visión se deja leer, en efecto, como una metáfora de la memoria. Se trata de intentar mirar los recuerdos mismos con ojos de niño. Así, el vidrio borroso que limita la vista en el presente simboliza también la dificultad de acceder al pasado, como ocurre en "Autobiografía de Irene": "A través de un vidrio, en la ventanilla de un tren, vi su último rostro, enamorado y triste, borrado por las imágenes superpuestas de mi vida futura" (1: 162).

Esta percepción infantil con su valor mnemónico implica que los “acontecimientos" narrados, a menudo violentos y crueles (como el crimen en "Cielo de claraboyas" o la violación en "La calle Sarandí”), no sean explicados sino evocados: es que aluden a la

\footnotetext{
El énfasis es mío en todas las citas, a menos que se indique lo contrario.

5 En "Viaje olvidado" por ejemplo, la niña escucha / la adulta recuerda "palabras atroces, llenas de sangre" y "palabras oscuras como pecados", Vol. 1, 74. Aquí vienen otros ejemplos, tomados de "La siesta en el cedro": "No sé qué voluptuosidad dormía en esa palabra color marfil."; "la palabra cambió de color, se puso negra, del color de un secreto horrible, que mata", Vol. 1, 43.
}

Revista Iberoamericana, Vol. LXXXI, Núm. 254, Enero-Marzo 2016, 71-89 ISSN 0034-9631 (Impreso) ISSN 2154-4794 (Electrónico) 
vez a la visión de un niño que no interpreta y a una memoria traumatizada. De este modo, la trama resulta varias veces desorganizada $y$, cuando hay un desenlace, el narrador lo expone sin entenderlo. En "La casa de los relojes", por ejemplo, el niño que describe la escena del jorobado planchado ${ }^{6}$ es capaz de observar todos los detalles de la acción criminal sin explicarlos. Fue Sylvia Molloy la primera en subrayar esta aceptación inmediata de la crueldad en los cuentos de Silvina Ocampo (en su artículo de 1978). Si el narrador/el niño no tienen ninguna distancia crítica frente a esta crueldad, la disparidad entre su postura y el supuesto horror que siente el lector en función de sus (supuestos) referentes morales puede generar un efecto irónico, como analiza Daniel Balderston: "no hay ironía o crítica acerca de la crueldad central del cuento [...]; si hay perspectiva irónica, surge de la distancia entre el narrador 'inocente' o mendaz y el universo moral 'normal' de autora y lectores" (747). La ironía, en los cuentos de Ocampo, resulta así de la simultaneidad entre la perspectiva aparente, explícita, del niño y la perspectiva implícita del lector, que muestra el verdadero sentido. Para Marta López-Luaces, si en general la materia narrativa de esos cuentos produce cierta ambivalencia (irónica o no), es porque nunca se presenta desde una sola perspectiva sino desde varias igualmente posibles, y muchas veces contradictorias (27-28). Entrarían en tensión, constantemente, la voz del adulto que quiere imponer su imagen hipócritamente nostálgica de la infancia y la voz de los niños. ${ }^{7}$ Es así como en varios cuentos se producen cambios, confusiones o desdoblamientos de las voces narrativas, a veces con superposiciones de pronombres personales. $^{8}$

Si los límites de la visión se refieren a una dificultad de recordar, otros motivos figuran directamente la memoria en los cuentos de Viaje olvidado, como el baúl, el armario o la casa. Estos objetos y espacios constituyen metáforas del cuerpo y moradas de un pasado susceptible de actuar en el presente (de volverse presente): contienen muebles, objetos, juguetes, vestidos que están vivos, animados como las partes del cuerpo. Como expone Gaston Bachelard en su Poétique de la rêverie (en el capítulo sobre "la ensoñación hacia la infancia"), la memoria que atribuye una vida a los objetos funciona de la misma manera que la percepción infantil (99-103). Lo expresa cabalmente el famoso comentario que hizo Victoria Ocampo de los primeros cuentos de su hermana menor: "Se tiene la impresión de que los personajes son cosas y las cosas personajes, como en la infancia" (120). Las numerosas personificaciones o humanizaciones que

${ }_{6}$ En este cuento, unos jóvenes matan a un relojero jorobado planchando su giba con una máquina de tintorería.

7 A propósito de los efectos contradictorios de la nostalgia y del terror en la obra de Ocampo, véase Mackintosh, 70-75.

8 Por ejemplo en los cuentos "Autobiografía de Irene", "El pecado mortal", "El diario de Porfirio Bernal", "El bosque de los helechos" o "Atropos".

Revista Iberoamericana, Vol. LXXXII, Núm. 254, Enero-Marzo 2016, 71-89 ISSN 0034-9631 (Impreso)

ISSN 2154-4794 (Electrónico) 
reflejan la perspectiva infantil conciernen en particular a $\operatorname{los}_{0 j o{ }^{9}} \mathrm{y}$ a $\operatorname{los}$ vestidos, ${ }^{10}$ que se vuelven verdaderos actores. A la inversa, los sentimientos son corporeizados, materializados por comparaciones y metáforas. ${ }^{11}$ El estilo animista de Viaje olvidado parece ser la matriz de las numerosas metamorfosis de los cuentos posteriores; ${ }^{12}$ como si estas hubieran surgido del lenguaje desarrollado para transmitir la creencia infantil en la vida de los objetos así como en la humanidad potencial de los animales o, más bien, en la animalidad de los hombres. Cincuenta años después de Viaje olvidado, el narrador de "El sombrero metamórfico" (en Y así sucesivamente, publicado en 1987) declara: "Los objetos son como las personas, malas o buenas" (2: 172).

\section{Poderes VISIONARIOS DE LOS NIÑOS}

En el mundo cuentístico de Silvina Ocampo aparece una distinción sistemática entre los modos perceptivos correspondiendo al "mirar"/“escuchar" y al "ver"/“oír". El primero, que supone una intencionalidad y/o un deseo en el presente (se mira para seducir o para espiar, por ejemplo), remite a la actitud adulta, habitual, activa, mientras que el segundo modo implica una disponibilidad inconsciente al destino que incluye y transforma la memoria. La actitud contemplativa o la videncia propia de los niños consiste en poder pre-ver, adivinar el futuro, ${ }^{13}$ lo cual no se opone a la capacidad de

9 Por ejemplo: "en ese momento vi que había montones de ojos a mi alrededor que lloraban", en "El pasaporte perdido", Vol. 1, 28; "Por entre las conversaciones los ojos de Leonor se abrían paso hasta la ventanas en busca de un pedazo de cielo azul enteramente cubierto, ahora, por las nubes", en "Extraña visita", Vol. 1, 53.

10 Por ejemplo: "llevaba un vestido que lloraba de soledad en el brillo de la noche", en "El pasaporte perdido", Vol. 1 28; "las ropas tendidas parecían personas y las verdaderas personas ropas tendidas; les dije adiós. Dije adiós al vestido azul de Filomena, al corpiño de Carmen, a la camisa a rayas de Damián [...]", en "Éxodo", Vol. 1, 319.

11 Por ejemplo: "disminuía levemente alrededor de ellas ese cariño que era del color del sol que las unía en verano", en "El Remanso", Vol. 1, 20; "los chicos escondieron abundantes risas detrás de la puerta por donde la veían llegar", en "El caballo muerto", Vol. 1, 22; "El odio o la indiferencia [...] estaban ahí delante de él palpables y sólidos como una pared de piedra", en "La enemistad de las cosas", Vol. 1, 2425. En "La cabeza pegada al vidrio", Mlle Dargère "[apoya] su melancolía sobre la balaustrada", Vol. 1, 47. En "Nocturno": "El miedo, cuidadosamente guardado, se asoma con cara de ladrón, lo agarra de la mano, le sonríe grande y adulto como un monstruo", Vol. 1, 52.

12 Por ejemplo: el trapo del perro "Pier" se animiza. En "Del color de los vidrios", "las botellas tenían vida propia", Vol. 2, 265; los libros ("Los libros voladores") se suicidan, Vol. 2, 273; la máscara en "El banquete" es la persona (al arrancar la máscara bajo la cual se ahogaba, Elida muere); el disfraz es la persona ("Los celosos"), la apariencia, el sueño es la realidad ("Keif"). Es así como en "Fidelidad", el narrador se da cuenta de que en realidad se enamoró de una forma, de un vestido: "Se trataba del vestido de una mujer, y como ese vestido revestía un cuerpo creía que me había enamorado del cuerpo", Vol. 2, 79.

13 Son niños adivinos: Irene ("Autobiografía de Irene"), Magush en el cuento epónimo, Aurora en "La sibila", Porfiria en "El diario de Porfiria Bernal", la narradora de "La muñeca", Luz en "Soñadora

Revista Iberoamericana, Vol. LXXXII, Núm. 254, Enero-Marzo 2016, $71-89$ 
inventarlo. El ejemplo más claro de este poder es el de la niña Porfiria que escribe un diario del porvenir, de lo que todavía no ha ocurrido. Su clarividencia desmantela la posibilidad o el sentido mismo de la secuencia cronológica, puesto que el futuro ya ha sido escrito por la niña. Porfiria no predice sino que imagina. Crear, contar, no es recordar sino olvidar e inventar: "Escribir antes o después que sucedan las cosas es lo mismo: inventar es más fácil que recordar", en "El diario de Porfiria Bernal” (1: 469). Sin embargo, en la mayoría de los otros casos, la invención del futuro o la creación de objetos no son libres, no obedecen a la conciencia de la vidente sino que surgen de unos sueños presentados como incontrolables (volveré a este aspecto más adelante).

Este don encuentra su equivalente inverso en el recordar o volver a ver el pasado que antecede la muerte y señala su cercanía. ${ }^{14}$ En la mayoría de los casos, el recuerdo o la videncia son un signo o un agente incontrolable de muerte. Por ejemplo, en su "Autobiografía" la pobre Irene pre-ve a los quince años la muerte de su padre, meses antes de que ocurra: "Me creí culpable de la muerte de mi padre. Lo había matado al imaginarlo muerto" (1:158). Se cree asimismo responsable de todo lo que sucede, como la niña de "La muñeca" que declara: "Preferiría no ser yo. Soy adivina. Sospecho a veces que no adivino el porvenir sino que lo provoco" (2: 89). Esta visión performativa, y en particular la de la muerte del padre, se puede interpretar en términos psicoanalíticos como un signo de la melancolía de estos personajes que experimentan una regresión al "narcisismo primario", es decir, según Freud, al primer narcisismo del niño que se toma a sí mismo como objeto de amor antes de poder elegir objetos exteriores, ${ }^{15}$ tal estado corresponde a la creencia del niño en la omnipotencia de sus pensamientos.

En vano trata Irene de tener visiones agradables. En "Clotilde Ifrán” también la visión coincide con la muerte de la niña: "Una luz oscura resplandeció en sus ojos enormes" (2: 73). En "La divina", la narradora lee las manos de los pasajeros de un barco y descubre que una misma tragedia los reúne. Años antes, había consultado a la Divina Irma Riensi quien la veía asociada al agua y a un viaje. El hecho de que el barco se hunda parece confirmar que la visión (adivinación) está destinada a anunciar la muerte, la tragedia; sin embargo, alguien la recoge "por uno de esos milagros que revelan, según dijo, la existencia de Dios" (2: 104). "Dios", la mirada -generalmente perdida- de Otro desde arriba, parece ser lo único que pueda salvar a los videntes. En este sentido, el deseo de mirar o de espiar puede interpretarse como una consecuencia

compulsiva" y Cristina Ladivina en "Cornelia frente al espejo".

14 En cuanto a la asociación entre recuerdo y muerte, véanse por ejemplo "Autobiografía de Irene", "El castigo" ("Recordar el pasado me mata", Vol. 1, 281) o "Cornelia frente al espejo".

15 Freud desarrolla la noción de narcisismo primario en su ensayo "Introducción al narcisismo" (1914), y la articula con la melancolía en "Duelo y melancolía" (1915): "si nos fuera lícito suponer que nuestras deducciones coincidían con la realidad, no vacilaríamos en integrar entre las características de la melancolía, la regresión de la carga del objeto a la fase oral de la libido, perteneciente aún al narcisismo", 1846. Volveré a este texto en mis conclusiones.

Revista Iberoamericana, Vol. LXXXII, Núm. 254, Enero-Marzo 2016, 71-89 ISSN 0034-9631 (Impreso)

ISSN 2154-4794 (Electrónico) 
de la pérdida, de la falta o ausencia de una mirada de amor de un Otro protector, ${ }^{16}$ sea este otro la madre o la nodriza, Dios o el amante.

También logra salvarse de sus sueños mortíferos la narradora del cuento tardío "Soñadora compulsiva" (Cornelia frente al espejo, 1988): Luz, de once años, sueña que Armindo, un chico que conoció en la calle, vuelve para violarla y matarla y que luego ella sube a un altillo y se cae. Al despertarse, decide ir en contra de sus sueños y destruir su poder de adivinación para no morir más. Al final del cuento, saca como premio de un concurso televisivo un pasaje para Bariloche. Subiendo al bus, se olvida de todo su pasado y se prepara a conocer otro mundo. Este cuento sugiere que, si bien no es posible controlar sus visiones, dominar las pulsiones de muerte surgidas del inconsciente (la visión en muchos casos se identifica con el sueño), se puede en cambio renunciar a su "don" (su melancolía) para "viajar", "descubrir otro mundo", mirarlo desde el presente. Pero, para eso, hay que "olvidar" el pasado, lo que la mayoría de los personajes no pueden o, más bien, no quieren hacer. Como declara la narradora de "Los retratos apócrifos": "En el olvido está mi esperanza, en el recuerdo mi tortura, pero lo más horrible de todo es que prefiero el recuerdo antes que el olvido, y la tortura antes que la esperanza" (2: 295). La soñadora compulsiva significativamente llamada Luz constituye entonces una excepción entre los personajes dotados de poder visionario y los entregados a las imágenes de la memoria.

Los adultos que vuelven a ver su pasado justo antes de morir, como también los enfermos, cercanos a la muerte, vuelven a ese estado infantil en el que la mirada está abierta al destino y tiene la cualidad de la videncia. ${ }^{17}$ Esta apertura no significa una libertad de decisión sino una aceptación del destino, que implica una anulación de la cronología y una capacidad para percibir relaciones de simultaneidad entre las edades más distantes. Tal correspondencia entre la posición ante mortem y la infancia aparece tematizada en el discurso del sabio Albino Orma (en el cuento que lleva su nombre), según el cual la vida es simétrica como una mancha de tinta: “Todo se repetía: si a los ocho de haber nacido él había sufrido un accidente, ocho años antes de morir sufriría un accidente similar" (2: 65). Si los adultos, al morir, reanudan con la infancia, es que los niños son sabios potenciales y “viejos". ${ }^{18}$ En uno de los últimos cuentos de Ocampo,

${ }_{16}$ La mayúscula remite a la definición psicoanalítica del “Otro”, que ha sido desarrollada por Jacques Lacan para designar la instancia que separa al sujeto del objeto de su deseo, introduciendo entre ambos una mediación simbólica (la del lenguaje, fundamentalmente); ver "Fonction..."). En este sentido, el sujeto recibe su identidad simbólica del Otro - a partir del momento en el que entra en el lenguaje.

17 Es así como son "videntes" el enfermo Efrén en "El mal", Valentín Brumana en "La revelación" o la enferma de "Visiones".

18 En los siguientes cuentos se invierte el esquema temporal, a tal punto que en unos casos los niños se vuelven profesores o padres de los adultos: "Cartas confidenciales", "Ulises", "Albino Orma”, "Clotilde Ifrán", "La lección de dibujo", "Del color de los vidrios", "Atropos" y "La raza inextinguible". En unos cuentos encontramos niños que no han crecido por voluntad propia (como Icera, en el cuento epónimo)

Revista Iberoamericana, Vol. LXXXII, Núm. 254, Enero-Marzo 2016, $71-89$ 
"Anotaciones", la narradora afirma: "No hay diferencia entre el viejo y el niño. El viejo y el niño son iguales" (2: 365).

La relación entre mirada, infancia y muerte se confirma en el caso de los niños que sufren impedimentos físicos o mentales. Al contrario de Porfiria, Irene o Cornelia, esos personajes son inconscientes de su poder vidente o mágico, pero su ejercicio involuntario suele ser peligroso o directamente mortífero. Si bien puede parecer que la carencia de facultad mental o de audición, que los aísla en su mundo, define las condiciones de un paraíso infantil inaccesible a los demás y ajeno a la "tortura" del recuerdo, este "paraíso" no implica ninguna nostalgia, ya que coincide sistemáticamente con la muerte. Así, los niños sordomudos de "Tales eran sus rostros", de vuelta de una excursión al mar, saltan del avión y vuelan en el cielo con alas. Su profesora, que vive el evento como una revelación, exclama que se han convertido en ángeles, pero la razón autoriza, o exige, interpretar este acto de los pequeños sordomudos como un suicidio y sus alas como un producto imaginario de la profesora. Por su parte, los niños con retraso mental del cuento "Ana Valerga", logran dar vida a estatuas por la fuerza de su creencia; pero la narración termina cuando uno de ellos está a punto de morir entre las flechas de unos indios de mármol. También es anormal y aislada la niña Isis (en el cuento epónimo) que nunca juega, permanece inmóvil y apenas habla: "nunca miraba algo que le hiciera mover el cuello o los ojos" (1:364). Esta condición le permite transformarse ella misma en un misterioso animal que es objeto exclusivo de su mirada; un animal que, según la narradora, "no parecía real sino dibujado en la arena" del jardín zoológico (1: 365). Si la inmovilidad y la desaparición de Isis ${ }^{19}$ dan cuenta de un estado perceptivo extraordinario, este es muy similar, una vez más, a la muerte. Y si, en varios otros cuentos, la muerte aparece como un nuevo principio, un espacio alternativo para la infancia, ${ }^{20}$ esta "alternativa" implica que la infancia no tiene en la vida el espacio que le conviene.

Todas estas muertes y metamorfosis de las que los niños son los sujetos o los objetos muestran, más que su poder, su posición fundamentalmente variable. Esta inestabilidad ontológica explica también la complicidad particular de los niños con los animales. En los cuentos de Ocampo los animales pueden ser figuras simbólicas -el caballo, en

o por un trauma (en "El bosque de los helechos"). En otros cuentos la narradora, reflexionando acerca de la edad, explicita la relación entre vejez e infancia; ver "La lección de dibujo", "La nave" o "Los retratos apócrifos". Leemos, por ejemplo, en este último cuento: "Siempre pensé que las edades son todas crueles, y que se compensan o tendrían que compensarse las unas con las otras. [...] La vejez es un disfraz con aditamentos inútiles. Si los viejos parecen disfrazados, los niños también. Esas edades carecen de naturalidad. Nadie acepta ser viejo porque nadie sabe serlo, como un árbol o como una piedra preciosa", Vol. 2, 294-295.

19 La narradora cuenta: "No quise verla mientras se transformaba. Cuando me volví para mirarla vi un montón de ropa que estaba ya en el suelo. La busqué. La esperé. La perdí”, Vol. 1, 365.

${ }^{20}$ Léanse, entre otros cuentos, "Las dos casas de Olivos", "La siesta en el cedro" y "Clotilde Ifrán".

Revista Iberoamericana, Vol. LXXXII, Núm. 254, Enero-Marzo 2016, 71-89 ISSN 0034-9631 (Impreso)

ISSN 2154-4794 (Electrónico) 
particular- ${ }^{21}$ y esconder una conciencia humana (como en "La liebre dorada"). Pero se detecta en otros cuentos una complicidad mayor entre niños y animales, ambos seres dominados (como en "Fuera de las jaulas"). Es un niño el que, en un cuento de Ocampo, sistematiza el principio de correspondencia entre las especies: "Horacio decía que a cada hombre le corresponde parecerse a un animal, o que a cada animal le corresponde parecerse a un hombre" ("La muñeca", 2: 94). Esta correspondencia que implica cierta violencia - "Los hombres se comen los unos a los otros, como los animales", en "La peluca" (2:401)-da lugar a la multitud de metamorfosis ${ }^{22}$ e intercambios entre personajes humanos y animales que ya he señalado.

\section{IMPROPIEDAD DE LA INFANCIA}

En los cuentos de Silvina Ocampo la restricción de la visión, las metáforas espaciales y las materializaciones, las superficies especulares y fotográficas, los retratos y los dibujos $^{23}$ así como las metamorfosis apuntan hacia la figuración del tiempo en el espacio y en sus objetos, revelando una dimensión espacial de la temporalidad. Desde este punto de vista, se puede plantear que Ocampo crea "imágenes-tiempo" -retomando la expresión que Gilles Deleuze aplica al cine moderno-, en la medida en que muestra la coexistencia de una imagen actual (en el presente) y de una imagen virtual (el pasado en el presente). El análisis del cuento "Magush" que propone López-Luaces parece un comentario de la noción deleuziana de imagen-tiempo, más específicamente de la que el filósofo llama "cristal". En la "imagen cristal" del cine moderno como en el mundo cuentístico de Ocampo, "le temps se scinde en même temps qu'il se pose ou se déroule: il se scinde en deux jets dissymétriques dont l'un fait passer tout le présent, et dont l'autre conserve tout le passé. Le temps consiste dans cette scission, et c'est elle, c'est lui qu'on voit dans le cristal" (Deleuze 108-109). "Magush" nos presenta a un adolescente capaz de leer el destino en las ventanas del edificio vecino y de engañar a los curiosos “entregándoles [otro] destino como si fuese el de ellos” (1: 218). Según López-Luaces,

${ }^{21}$ El caballo simboliza el mito de la pureza (infantil) en "Las dos casas de Olivos" (donde un caballo blanco lleva a las niñas muertas al cielo) y en "El caballo muerto" (donde el mismo animal es matado por un chico caracterizado por "decir cosas atroces").

22 Se encuentra una correspondencia o simetría entre los niños o las mujeres y los animales por ejemplo en "Azabache", "Éxodo", "Keif”, "Carl Herst" o "La peluca”, y una metamorfosis de o hacia la condición animal en "El diario de Porfiria Bernal", "Isis", "La gallina de membrillo", "Miren cómo se aman", "El rival", "Pier" o "Okno, el esclavo". En "Los sueños de Leopoldina” el narrador es el perro.

${ }^{23}$ Léanse, en referencia al retrato, los cuentos "Los retratos apócrifos", "El goce y la penitencia", "El novio de Sibila", "El cuaderno"; y, en referencia al dibujo, los cuentos "Azabache", "Tales eran sus rostros" y "La lección de dibujo".

\footnotetext{
Revista Iberoamericana,
ISOl.
} 
el pasado no resulta ni motivo de nostalgia ni causa u origen del presente, sino que se vuelve un espacio nuevo, que constantemente se transforma e irrumpe en el presente. El pasado es una lectura más dentro de las varias lecturas posibles que se dan en el edificio de enfrente. Tampoco el futuro que lee e interpreta en ese edificio se presenta como consecuencia del presente - tal como lo supondría una concepción del tiempo progresivo, lineal, determinista-, sino que se entiende como una de muchas realidades posibles. (López-Luaces 71)

El problema o el núcleo de tal sistema está en la imposibilidad de cambiar su destino por otro o incluso de decidir entre las diversas realidades posibles. El vidente Magush y su amigo el narrador prefieren contemplar las imágenes de su destino en vez de vivirlas: "Después, cuando fui al encuentro de esos acontecimientos, la realidad me pareció un tanto descolorida y mi novia tal vez menos hermosa" (1:218). El cuento concluye del siguiente modo: "A mí me fascina siempre el destino de Magush y a él (por malo que sea) el mío, pero en el fondo lo único que deseamos los dos es seguir contemplando las ventanas de esa casa y regalar a otros nuestro mundo, mientras no nos parezca extraordinario" (1: 219). La multitud de fantasmas, ${ }^{24}$ dobles, ${ }^{25}$ muñecas, ${ }^{26}$ gemelos, sombras, ecos, reflejos, de vidas prestadas, intercambiadas, soñadas, sospechadas, inventadas, de metamorfosis en animal o en objeto, en los cuentos de Ocampo condensan el mismo presentimiento de una doble vida, una manifiesta y otra latente o potencial, pero finalmente inalcanzable y objeto, asimismo, de una profunda melancolía, una tortura "preferida" según las palabras ya citadas de "Los retratos apócrifos". La melancolía, aquí, se funda en una unión paradójica entre una conciencia del peso de la fatalidad ${ }^{27}$ y un sentimiento de la irrealidad de la existencia. ${ }^{28}$ En consecuencia: "Sin duda, todo recuerdo es doloroso. Más vale pensar en lo actual, en lo que estamos viendo. En cierto sentido, podría decir que no hay cosas extrañas o inesperadas. Todo es lo de siempre,

24 Por ejemplo en los cuentos "El siniestro del Ecuador" y en "George Selwyn".

25 Véanse los cuentos "La continuación", "La casa de azúcar" "Casi el reflejo de la otra", "Nosotros", "Carta perdida en un cajón", "La vida clandestina", "Keif”, "El para otra", "La próxima vez", "El miedo", entre otros. La identificación con un doble suele llevar a la muerte, al final del amor o a la desdicha.

${ }^{26}$ Las muñecas son figuras que sustituyen o simbolizan personas humanas, eventualmente con pensamiento autónomo, en los siguientes cuentos: "Día de santo", "El incesto", "El pecado mortal", "La hija del toro", "La muñeca", "Cornelia frente al espejo" y "Atropos". En "Memorias secretas de una muñeca", como indica el título, es una muñeca en persona la que toma la palabra. En "Icera", la niña se transforma poco a poco en muñeca.

27 "No hay niño desdichado que después sea feliz [...] es un error creer que el destino pueda cambiarlo. [...] El hombre lleva su cruz desde el principio: hay cruces de madera tosca, de aluminio, de cobre, de plata o de oro, pero todas son cruces", en "Carta perdida en un cajón", Vol. 1, 238.

28 Declara Cornelia a uno de sus visitantes: "Si usted matara mi imagen en el espejo, me mataría también a mí. [...] Nosotros, los seres humanos, somos irreales como las imágenes", en "Cornelia frente al espejo", Vol. 2, 237.

Revista Iberoamericana, Vol. LXXXII, Núm. 254, Enero-Marzo 2016, 71-89 ISSN 0034-9631 (Impreso) 
lo mismo" -"La nave" (2: 352)-. Finalmente, el dolor del pasado devora o congela el presente impidiéndole ser sorprendente, "extraño o inesperado".

Las imágenes que sustituyen una duración temporal y la congelan son monstruosas; son deformaciones que, como sugiere la etimología de la palabra, albergan una señal, un aviso, una revelación. ${ }^{29}$ Lo monstruoso aparece, en el mundo de Silvina Ocampo, como la modalidad visual de lo imposible, lo inaccesible en la realidad cotidiana. Judith Podlubne, en su artículo dedicado a "la narración de la infancia en Viaje olvidado", sugiere que esta imagen es la de la infancia misma: "la infancia no regresa a la memoria como el recuerdo de un tiempo terminado, sobre el cual se conserva alguna posesión, sino como una 'imagen indescifrable' de sí misma que aún perdura" (96). La imagen del recuerdo, como la fotografía, escapa al reconocimiento y parece irreal; tiene una consistencia onírica, según afirma el personaje Armando Heredia en el cuaderno de los sueños: "No hay distinción en la faz de nuestras experiencias; algunas son vividas, otras opacas; algunas agradables, otras son una agonía para el recuerdo; pero no hay cómo saber cuáles fueron sueños y cuáles realidad", en "El impostor" (1:143)-. ${ }^{30}$ En un cuento escrito décadas más tarde, la narradora de "Keif” enuncia: “¿dónde estaba la inmensa ola de mi sueño recurrente que me cubriría, ese sueño que me había perseguido desde la infancia? No. No era un sueño. ¿En qué se diferenciaba el sueño de la realidad? En la duración, en el olor" (2: 131). Como muestran estas citas, el sueño no es una máscara que se superpone al recuerdo vivido para transfigurarlo sino que "es la sombra que transmite a esos recuerdos la sospecha de impropiedad en que se gestan" (Podlubne 101). Podlubne concluye: "El intento narrativo de Viaje olvidado es menos el de recrear de una manera inocente o interesada en el pasado infantil que el de encontrar la forma de decir su impropiedad" (102). En "Los retratos apócrifos" la narradora evoca una miniatura para la que posó ella, inspirada en el cuadro de Reynolds La edad de la inocencia: "Esa miniatura se ha perdido y siento que, si no la encuentro, perderé para siempre mi inocencia" (2: 294). Al final del cuento, afirma que este cuadro nunca existió; el recuerdo de la imagen sólo le servía para establecer la ficción de una identidad basada en el mito de la inocencia infantil. La desaparición de la miniatura o, más bien, la constatación de su inexistencia, traduce una desapropiación de la identidad de la narradora y muestra la impropiedad de su memoria. Ningún recuerdo (ninguna edad) le pertenece, y descubre, o reconoce, que nunca ha sido inocente.

${ }^{29}$ La voz latina monstrum, forjada a partir del infinitivo monere (“avisar, advertir"), pertenecía al vocabulario religioso y denotaba un prodigio, un suceso sobrenatural que anunciaba la voluntad de los dioses y que había que descifrar.

${ }^{30}$ En cursivas en el texto original.

Revista Iberoamericana, Vol. LXXXII, Núm. 254, Enero-Marzo 2016, $71-89$ ISSN 0034-9631 (Impreso)

ISSN 2154-4794 (Electrónico) 


\section{JUEGOS CRUELES DE LOS NIÑOS E IMPOTENCIA DE LA VISIÓN}

Cabe examinar más detenidamente, ahora, cómo es (mal)tratado este mito de la inocencia infantil en los cuentos de Silvina Ocampo, en relación con la noción de melancolía. La recurrencia de niños criminales, crueles y perversos en la obra de la escritora argentina no ha dejado de llamar la atención de la crítica. ${ }^{31} \mathrm{Su}$ lista es muy larga. ${ }^{32}$ Por tomar un ejemplo, consideremos dos de ellos en el cuento "El árbol grabado". La niña narradora cuenta que, un día de Carnaval, disfrazada de diablo, ${ }^{33}$ incitó a Clorindo, vestido de fantasma, a colocar un hormiguero en el interior de una tarta. Para castigarlo, Don Locadio, el abuelo de Clorindo, lo desnudó y lo golpeó a latigazos. En reacción, el niño "tomó su cuchillito y sin vacilar se lo clavó a don Locadio en el corazón” (1: 448). La narradora concluye misteriosamente: “Por aquí pasó el diablo, que se apoderó del alma de Clorindo’ dijeron las personas, después del crimen, al ver los troncos marcados. Y yo me sentí culpable" (1: 448). Recuérdese que una de las funciones originarias de la fiesta de Carnaval en la Edad Media occidental consistía en autorizar una inversión liberadora de los papeles habituales. ${ }^{34}$ Por eso, quizá, la niña tradicionalmente inocente se viste de diablo. Pero en el mundo de Silvina Ocampo, el vestido tiene un papel activo, a veces mortífero, en la persona que lo lleva. En la última frase de "El árbol grabado", la narradora sugiere que, por su apariencia diabólica, se podría haber encontrado bajo la influencia del Diablo y se habría transformado contra su voluntad en un instrumento del Mal. Se insinúa también que Clorindo, por su parte, ha reproducido en su acto criminal el gesto de su juego favorito que consistía en grabar corazones en los troncos de los árboles en los cuales "clavaba su cuchillo, probando su puntería, que era bastante buena" (1:448). El crimen parece haber nacido así de una combinación entre un disfraz y un juego.

Es que el juego, actividad infantil por excelencia, no suele ser un entretenimiento en la cuentística ocampiana, sino una apariencia engañosa ("Carta de despedida"), un refugio ("El pecado mortal", "Atropos"), un trabajo ("La raza inextinguible") o un medio

31 Uno de los estudios más famosos sobre los cuentos de Ocampo es el capítulo que Matamoro le dedicó en su libro Oligarquía y literatura en 1975: "La nena terrible".

32 Podemos citar, en Viaje olvidado: "El vendedor de estatuas"; en La furia: "La boda", "La sibila", "El vestido de terciopelo", "La furia", "Voz en el teléfono", "La oración”. En Las invitadas: "La hija del toro", "La revelación", "El árbol grabado", "El diario de Porfiria Bernal". Blas Matamoro cita también, como "niños terribles", los de "Fuera de las jaulas", de "Celestina", de "El hórreo" y de "Las invitadas".

33 El cuento "Clotilde Ifrán” presenta una configuración diferente de los mismos motivos del Carnaval asociado a una fiesta de cumpleaños, de un niño, del diablo y de la muerte. El Carnaval propicia aquí una igualación entre infancia y muerte.

34 Ver Bakhtin: “À l'opposé de la fête officielle, le carnaval était le triomphe d'une sorte d'affranchissement provisoire de la vérité dominante et du régime existant, d'abolition de tous les rapports hiérarchiques, privilèges, règles et tabous. C'était l'authentique fête du temps, celle du devenir, des alternances et des renouveaux. Elle s'opposait à toute perpétuation, à tout parachèvement et terme"; en L'CEuvre, 18.

Revista Iberoamericana, Vol. LXXXII, Núm. 254, Enero-Marzo 2016, 71-89 ISSN 0034-9631 (Impreso)

ISSN 2154-4794 (Electrónico) 
de actuar sobre la realidad, de transformarla ("La hija del toro", "La soga") o también de entrar en comunicación con otra dimensión ("Amancio Luna"). Su tratamiento trastorna la representación inocente de la infancia hasta hacer de ella el lugar mismo de la perversidad. En "La oración", un crimen se produce "en medio de esos juegos que parecían inocentes" (1:285); en "Albino Orma" los juegos son "inocentemente obscenos", "tan complicados que sólo un niño podría entenderlos" (2: 66). El juego es un término que sirve a los adultos para calificar las actividades a veces malignas de los niños; es, como el vestido del diablo en "El árbol grabado", un disfraz. Un niño escribe a su madrina: "Crees que juego cuando me ves en los columpios, o con niños de mi edad jugando a la rayuela, o con perros. ¡Cómo te equivocas! Si jugar es divertirse, nunca juego. ¿Qué nombre puede tener lo que hago cuando parece que me entretengo?" -"Carta de despedida" (1:449)-. Según Blas Matamoro, el juego con la apariencia que practican los niños de Ocampo ${ }^{35}$ sería un recurso vital para defenderse de los adultos que siempre amenazan con manipularlos:

Es ley en la vida del niño terrible la constante comedia: debe fingir para subsistir, ya que, si descubrieran su verdadera identidad, lo destruirían por criminal. Esta farsa infinita hace, de su máscara, un rostro, hasta el punto de que sólo si se mira al espejo puede tener noción de sí mismo: es pura apariencia especular, sin identidad real consigo mismo. (209-210)

El carácter fingido del juego infantil -fingido en cuanto inocente, destinado a tranquilizar a los adultos-se confirma, en algunos cuentos narrados por un(os) niño(s), por el evidente placer que encuentra(n) no sólo en "torturar" a los demás sino también en contar estas torturas. Los chicos de "La revelación", por ejemplo, dignos del "Niño proletario" de Osvaldo Lamborghini, se entretienen doblemente en cometer crueldades y en narrarlas:

Nos placía torturarlo. Lo acostábamos en una hamaca paraguaya con los bordes anudados para que no pudiera escapar, y lo mecíamos hasta que el vértigo le cerraba los ojos. Lo sentábamos en un columpio, enrollábamos las cuerdas laterales, para soltarlas de golpe y lanzarlo vertiginosamente en el espacio. No le permitíamos que probara los postres, que nosotros comíamos, pero le untábamos el pelo con dulce o con azúcar impalpable y lo hacíamos llorar. (1:325)

${ }^{35}$ Pezzoni, 212, y Molloy califican su conducta de paródica; el relato ocampiano sería asimismo una autoparodia. Escribe Molloy: "la parodia resulta en la obra de Silvina Ocampo una verdadera concepción de la literatura: en lugar de ser superficie que sugiere contenidos, la palabra agota esos contenidos reflejándolos, asumiéndolos, reduciéndolos a un plano único, el que le dicta su propia existencia", 24. Mi idea es que esta "concepción de la literatura" se plasma en los niños que, como la escritura, fingen.

Revista Iberoamericana, Vol. LXXXII, Núm. 254, Enero-Marzo 2016, 71-89 
De manera general, en los cuentos de Ocampo el juego y la tortura invierten sus características. Si el primero es un asunto muy serio, un trabajo eventualmente destinado a engañar a los adultos, la segunda, gratuita, es un placer en el que se revela una potencialidad generalmente oculta de los niños, el aspecto menos "propio" de la infancia. He comentado que el anciano prefiere la tortura del recuerdo a la serenidad del olvido. Si se considera que los niños todavía relativamente desprovistos de recuerdos prefieren también la tortura pero dirigida a otros, se puede inferir que la acumulación de la memoria enseña a aplicarse la tortura a sí mismo, quizá a encontrar en ello un placer superior, pasando a un registro mental.

Entre los niños y los ancianos está la edad adulta. Si los primeros son perversos, lo son también los adultos capaces de matar a sus hijos (en "Cielo de claraboyas", en "El retrato mal hecho"), de manipularlos ("La boda"), susceptibles de ignorar su muerte ("Los funámbulos", "Las fotografías") o de permanecer indiferentes a la misma ("La siesta en el cedro"). En el primer volumen de cuentos sobre todo (Viaje olvidado), la crueldad es perpetrada casi siempre por los adultos sobre los niños. En relación con los personajes infantiles que siguen en los otros volúmenes, los de Viaje olvidado son víctimas que sufren en silencio y parecen esperar el momento de su venganza. ${ }^{36}$ Matamoro ve en las conductas de los niños terribles -hijos de la gran burguesía- una respuesta frente al comportamiento represivo de los padres y de educadores igualmente terribles, cuya ambigüedad afectiva sería cuestionada en los cuentos (Matamoro 196): "la mutilación del afecto padre-hijo hace que el impulso afectivo del niño se convierta en agresión terrible" (200). Es obvio, en todo caso, que, en la relación turbia entre miembros de la familia, "los niños no son víctimas inocentes sino cómplices del abuso, quieren experimentar nuevas sensaciones" (160), como escribe Joanna Page al comparar el cuento de Silvina Ocampo "El pecado mortal” con la película de Lucrecia Martel La niña santa (2004). Según Page, muchas veces los niños "alcanzan un grado de poder subversivo sobre los adultos" (160-61). ${ }^{37}$ Es la tesis también de López-Luaces para quien, en la obra de Ocampo,

la crueldad infantil, a diferencia de la adulta, produce una visión alternativa de la realidad. Al volverse violentos, los niños producen lo extraño, ya que la posición que habitualmente les corresponde o se les adjudica es la de la pasividad, la debilidad, la falta de poder. La crueldad aparece entonces como una de las fuerzas creadoras de la infancia, por la cual los niños toman el poder. (76)

${ }^{36}$ La excepción notable es el ya citado "Vendedor de estatuas", hacia el final del volumen, donde se encuentra al primer niño diabólicamente perverso de la obra de Ocampo.

37 Otra versión de este artículo de Page figura (en inglés) como séptimo capítulo de su libro Crisis and Capitalism in Contemporary Argentine Cinema publicado en 2009. Aquí cito la versión en español de 2007.

Revista Iberoamericana, Vol.
LXXXII, Núm. 
Page y López-Luaces valoran así la infancia como un modo de subvertir las estructuras sociales del mundo adulto: familia, amistad, religión, educación. Según la perspectiva marxista de Matamoro, dicha subversión consiste en asumir el "mal" (el odio a la familia), pero no es revolucionaria (219). Refiriéndose a Sartre, Matamoro concluye que los niños malvados no quieren cuestionar o destruir el orden establecido sino alzarse contra este orden en actitud de resentimiento; necesitarían el orden para que subsistiera la diferencia entre el Mal y el Bien a partir de la cual se definen como malvados (Matamoro 220). De modo semejante, Adriana Astutti estima que el niño terrible es un traidor y que Ocampo misma, "como traidora, rompe un sistema en el instante en el que lo pone en evidencia, sin crear uno nuevo" ("Escribir" 79). Su escritura no crearía un nuevo dominio de lo "propio", de alguna identidad reconocible o simplemente posible, sino que sería un medio de impropiedad radical, un método para deshacer toda propiedad e identidad. Por eso la "visión alternativa" de la que habla López-Luaces sólo puede ser una visión melancólica. No produce ni propone otra realidad sino la muerte o la utopía imposible de una infancia a la cual se entrega la gestión del mundo y que forma una "raza inextinguible". ${ }^{38}$ Como analiza también Mónica Zapata, "los cuentos de Ocampo pueden producir una sensación de horror e incluso de rechazo, en la medida misma en que nos confrontan a la realización de lo prohibido. Sin embargo, no podemos decir que propongan una alternativa diferente a la ley que ponen al descubierto" (359). Para entender mejor la violencia que ejerce el niño y antes de articularla más precisamente con la melancolía, propongo volver a considerar ahora los (no) poderes de la visión y de la mirada en general, partiendo de la idea, ya comprobada, de que en los cuentos de Ocampo el niño figura un prototipo de esta actividad paradójica, a menudo asociada a una actitud pasiva.

Si bien las visiones en el sentido de apariciones son frecuentes en el mundo de Silvina Ocampo, en la mayoría de los casos no generan sorpresa ni dan poder sobre la realidad manifiesta; sólo pueden otorgar la conciencia de su pobreza, como en el caso citado de "Magush". La narradora del cuento "Visiones" explicita la limitación de su poder de videncia y la relativa pasividad en la que este poder la deja o que implica: “¿Qué imágenes me esperan ahora? Cambian como por magia. Veo una cabeza asomada en una ventana. [...] Ansío ver otra visión. Las provoco. ¿Cómo? Tengo un poder sobrenatural, pero limitado. No siempre consigo ver cosas hermosas ni tranquilizadoras" (1:351). En "Los objetos", "Los sueños de Leopoldina" o "Amada en el amado", los protagonistas hacen aparecer objetos a partir de sus recuerdos o de sus sueños, pero son molestos ("Los objetos"), inútiles ("Los sueños de Leopoldina") o de poca importancia ("Amada en el amado"). Dichos objetos sólo parecen poder servir en cuanto instrumentos de

38 En el cuento titulado "La raza inextinguible" se atribuye cierta dimensión mística a la visión infantil: "es verdad que algunos, entre nosotros, afirman que al reducirnos, a lo largo del tiempo, nuestra visión del mundo será más íntima y más humana", en Vol. 1, 306.

\footnotetext{
Revista Iberoamericana, Vo1. LXXXII, Núm. 254, Enero-Marzo 2016, $71-89$ 
sufrimiento: "Rara vez, por suerte, [estos objetos] le sirven para sufrir transformaciones [...]: el término sufrir está bien elegido pues en toda transformación hay sufrimiento" (2: 22). La narradora de "Visiones" enuncia también esta sentencia terrible: "Sufre menos el que sufre que aquel que ve sufrir" (1:347). Es que el ver se impone al vidente a pesar suyo. En cambio el que mira sufrir busca placer y/o poder en ello, aunque rara vez esté satisfecho. Una característica del mirar según Silvina Ocampo, en todo caso, es que enlaza, compromete al que mira con lo que ha mirado y lo culpabiliza. Es lo que descubre la narradora de "La oración" cuando espía el juego de un niño que se divierte en ahogar a uno de sus compañeros:

Yo miraba la escena, como en el cinematógrafo, sin pensar que hubiera podido intervenir. Cuando el niño soltó la cabeza de su adversario, éste se hundió en el barro silencioso. Hubo entonces una desbandada. Los niños huyeron. Comprendí que había asistido a un crimen, a un crimen en medio de esos juegos que parecían inocentes. (1:285)

La narradora luego esconde en su casa al niño criminal-al que la gente quiere linchar y que sigue cometiendo perversidades-, pues el espiar este crimen la ha hecho cómplice del mismo. En otros cuentos el impulso por mirar secretamente al otro desemboca en una reacción de violencia, de destrucción de este otro, en la que podemos leer una voluntad de borrar el sentimiento de culpa experimentado por el voyeur y, como nota Daniel Balderston, una frustración por ser excluido del secreto espiado (750-751). Es así como, por ejemplo, el espiar un acto de amor crea la voluntad de matar a los amantes en "Los mastines del templo de Adriano"; el escuchar una conversación secreta lleva al crimen a los narradores de "Voz en el teléfono" y de "La boda". También serían mirones, según Balderston, los videntes y los brujos que ya he mencionado -o sea, los que ven sin proponérselo, sin haber querido mirar, sino por el efecto de un don- , en la medida en la que este don sobrenatural no les sirve en rigor para nada:

la brujería frustrada se reduce a una especie de mironismo que ni siquiera provee placer al brujo [...] [N]o da placer el mironismo porque el espectador siente la necesidad de destruir lo que ve [...] [C]ualquier intento de contacto entre el yo y el otro se ve frustrado por el placer del crimen o del dolor del aislamiento. (Balderston 751)

Como he sugerido, una característica de los ancianos sería su capacidad para dirigir conscientemente la violencia hacia sí mismos. En cambio, cuando la violencia se ejerce contra los mirones adultos o niños, esta no se da como resultado de su propia voluntad sino como un castigo del exterior. En "La expiación” por ejemplo, Ruperto - descrito de este modo: "no era un hombre, era un par de ojos, sin cara, sin voz, sin cuerpo" (1:

Revista Iberoamericana, Vol. LXXXII, Núm. 254, Enero-Marzo 2016, $71-89$ ISSN 0034-9631 (Impreso)

ISSN 2154-4794 (Electrónico) 
404)-, ${ }^{39}$ que tiene una pasión misteriosa por mirar a la mujer de su mejor amigo, sueña que unos canarios picotean sus ojos y, cuando se despierta, está ciego. El sueño, aquí, a la vez metaforiza la culpa y es el instrumento real del castigo. Por mencionar otro caso con un personaje infantil, en el cuento "El pecado" una violencia externa - una violaciónviene a castigar el placer que la niña protagonista encuentra en mirar al sirviente por la cerradura cuando este va al baño, placer vivido como culpable. Esta "necesidad de destruir", de autodestruirse, de consumar la culpa y de exponerse al castigo proviene de la rabia alternativa a la melancolía provocada por la "inutilidad" del poder de la mirada.

\section{CONCLUSIÓN: ESCRITURA DE LA INFANCIA Y ORALIDAD MELANCÓLICA}

En los cuentos de Silvina Ocampo, el tratamiento de los modos perceptivos de la vista, la visión y la mirada, de la metamorfosis y de la destrucción, del disfraz y del juego deja constantemente la posibilidad de la lectura literal o del malentendido, haciendo surgir un mundo inquietante en el que el sentido figurado se confunde con el sentido propio, el disfraz con la desnudez, la inocencia con la crueldad, el juego con el crimen. Alejandra Pizarnik entendió muy bien este conflicto en el uso y la recepción del lenguaje en la obra cuentística de Ocampo: "el humor es obligado a nacer, casi siempre, del pie de la letra o, lo que es igual, del simulacro de la asimbolia o, lo que es igual: basta olvidar que el lenguaje está hecho de símbolos, para que el mundo se vuelva una representación de El Gran Hospicio del Mundo", 257-258. Según Adriana Astutti, semejante literarización o "asimbolia" fingida traiciona la presumida arbitrariedad de la lengua escrita al introducir en ella la oralidad. En la "voz" o más bien variación de voces de Silvina Ocampo, que "no representa la forma en que se habla, sino que dice la oralidad cifrada en lo que se dice, al poner a variar los dichos de esa oralidad" ("Escribir" 81), aparecen según Astutti “relentes de infancia" (71). Esta inestabilidad del lenguaje que amenaza su carácter metafórico y hunde sus raíces en la infancia puede ser caracterizada en términos psicoanalíticos -aunque no sean los de Astutti, quien se refiere más bien a Deleuze- como el resurgir de una fase anterior de la evolución del sujeto, fase en la que este todavía no domina los códigos de la sociedad que integra (no distingue, por ejemplo, el sentido literal del sentido figurado, metafórico, del lenguaje). ${ }^{40}$ Así, la "oralidad" que se manifiesta en los cuentos de Ocampo puede ser remitida a lo que la teoría psicoanalítica llama la fase oral, es decir, la primera etapa del desarrollo de la libido en la que "el placer sexual

39 En cursivas en el original.

40 En ningún momento pretendo aplicar estos términos a Silvina Ocampo como persona, sino al lenguaje que construyen sus cuentos. Si el psicoanálisis puede decir algo de la literatura, es que ambos reconocen el imperio que tiene el lenguaje sobre el ser humano, y que el primero concibe la segunda como una experiencia en sí (en cuanto exploración del lenguaje) y no (sólo) como expresión de una experiencia. (Léase, al respecto, la presentación de Pierre Piret al libro de Ginette Michaux). 
está ligado predominantemente a la excitación de la cavidad bucal y de los labios, que acompaña a la alimentación" (Laplanche y Pontalis 152). El modo de relación con el objeto propio de esta fase oral sería la incorporación (o identificación corporal), la cual puede desplazarse desde la actividad bucal y abarcar otras funciones, tales como la respiración y la visión (153). La visión, entonces, se entendería como una manera ambivalente, a la vez pasiva y activa -ya que la oposición entre actividad y pasividad no existiría todavía- de incorporar, de devorar lo mirado. Ahora bien, la "regresión" que supone la vuelta a, o la adopción de, la oralidad es precisamente lo que define la melancolía según Freud, siendo esta una relación de identificación narcisista con (o de incorporación de) un objeto perdido. En "Duelo y melancolía”, en efecto, Freud describe la melancolía como un duelo patológico, caracterizado por "la perturbación del amor propio" (1842): "en el duelo el mundo aparece desierto y empobrecido ante los ojos del sujeto. En la melancolía es el Yo lo que ofrece estos rasgos a la consideración del paciente" (1843), un Yo que "sabe a quién ha perdido, pero no lo que con él ha perdido" (1843). Esta interpretación permite a Freud "relacionar la melancolía con una pérdida de objeto substraída a la consciencia", a diferencia de lo que ocurre en el duelo (1843). En vez de efectuar el duelo de la persona o del "objeto", el melancólico entra en un paradójico e imposible duelo de sí mismo, de su propia imagen - de la imagen del otro identificado consigo mismo.

El efecto inquietante que crea la oralidad melancólica en los cuentos de Ocampo coincide así con otro fenómeno analizado por Freud, el de lo Unheimlich, generalmente traducido en castellano por "lo siniestro". En el famoso texto que le dedica en 1919, Freud nota que la manifestación siniestra de "todo lo que debía haber quedado oculto" (cita de Schelling) muchas veces toma la apariencia de un doble o de una repetición que corresponden a una fase anterior y reprimida de la evolución del yo: "El carácter siniestro sólo puede obedecer a que el 'doble’ es una formación perteneciente a las épocas psíquicas primitivas y superadas, en las cuales sin duda tenía un sentido menos hostil”" (2237). Freud precisa que este doble siniestro incluye también "todas las posibilidades de nuestra existencia que no han hallado realización y que la imaginación no se resigna a abandonar" (2236) - o sea, todos los “objetos" imaginarios de un "duelo" nunca acabado, de una melancolía subterránea que surge junto con el sentimiento de lo siniestro-.

Hay muchas muertes (repetidas) en los cuentos de Ocampo, pero lo que muere (y a la vez vuelve y se repite), fundamentalmente, con los diversos personajes, es la subjetividad misma, en cuanto constituida por el lenguaje. La infancia no es el "objeto" oscuro de la melancolía presente en la cuentística de Ocampo; es más bien el sujeto siniestro de un lenguaje melancólico, en duelo de sí mismo (un duelo paradójico e inconfesado).

De lo que se trata en los cuentos de Ocampo es de personajes, de situaciones o de objetos que concentran melancólicamente un tiempo bloqueado en la repetición no del pasado (no de alguna infancia perdida) sino del futuro pre-visto (un futuro en el que la

Revista Iberoamericana, Vol. LXXXII, Núm. 254, Enero-Marzo 2016, $71-89$ ISSN 0034-9631 (Impreso)

ISSN 2154-4794 (Electrónico) 
visión tiende a absorber el lenguaje). Una melancolía paradójica de otro destino, de otra vivencia del tiempo ocasionalmente figurada por el viaje. Los niños, los ancianos, los enfermos y los discapacitados - categorías combinables- son los seres más susceptibles de encontrar ese otro lado de la vida, que suele identificarse con la muerte. La infancia no encarna el otro lado (como es el caso, por ejemplo, en la obra de Julio Cortázar), sino que en ella se revela su inexistencia. Silvina Ocampo no cesa de delatar y de deconstruir la nostalgia del adulto hacia su infancia, de mostrar cómo ésta escapa de todo intento de definirla y de recordarla. No es deseable volver a ella: no conoce ni la "despreocupación" 41 -pues el porvenir le agobia tanto como el recuerdo oprime al adulto- ni la inocencia en el sentido moral del término. Esta infancia cruel, extraña, hasta irreconocible, designa una mirada oral que "incorpora" sus objetos y una lengua insegura de su poder de metaforización, repitiendo con efectos siniestros un deseo de visión que prescinda de las palabras.

\section{REFERENCIAS}

Astutti, Adriana. "Escribir como (cómo) una mujer: Victoria y Silvina Ocampo". MORA (Revista del Instituto Interdisciplinario de Estudios de Género) 6 (2000): 69-88. Andares clancos. Fábulas delmenor en Osvaldo Lamborghini, J. C. Onetti, Rubén Dario, J. L. Borges, Silvina Ocampo y Manuel Puig. Rosario: Beatriz Viterbo, 2001. Bachelard, Gaston. "Les rêveries vers l'enfance". La Poétique de la rêverie. París: Presses universitaires de France, 2005. 84-123.

Bakhtin, M. M. L'EEuvre de François Rabelais et la culture populaire au Moyen Age et sous la Renaissance. Andrée Robel, trad. París: Gallimard, 1970.

Balderston, Daniel. "Los cuentos crueles de Silvina Ocampo y Juan Rodolfo Wilcock". Revista iberoamericana XLIX/125 (octubre-diciembre 1983): 743-752.

Deleuze, Gilles. Cinéma./2, L’image-temps. París: Minuit, 1985.

Freud, Sigmund. "Introducción al narcisismo" [1914]. Obras completas [OC]. Luis López Ballesteros, trad. Biblioteca Nueva, 1948. 1760-1779.

"Duelo y melancolía” [1915]. Obras completas [OC]. Luis López Ballesteros, trad. Biblioteca Nueva, 1948. 1841-1850.

"Lo siniestro" [1919]. Obras completas [OC]. Luis López Ballesteros, trad. Biblioteca Nueva, 1948. 2224-2245.

Lacan, Jacques. "Fonction et champ de la parole et du langage". Ecrits. París: Seuil, 1966. 237-322.

${ }^{41}$ Esta despreocupación es una apariencia que los niños adoptan conscientemente: "sin perder la inocencia, pero perdiendo esa despreocupación aparente, tan característica de la infancia, los niños no pensaron en otra cosa"; en "Tales eran sus rostros", Vol. 1, 309.

Revista Iberoamericana, Vol. LXXXII, Núm. 254, Enero-Marzo 2016, 71-89 ISSN 0034-9631 (Impreso)

ISSN 2154-4794 (Electrónico) 
Laplanche, Jean, y Jean-Bertrand Pontalis. Diccionario de Psicoanálisis. Buenos Aires: Paidós, 1996.

López-Luaces, Marta. Ese extraño territorio: la representación de la infancia en tres escritoras latinoamericanas. Santiago de Chile: Editorial Cuarto Propio, 2001.

Mackintosh, Fiona Joy. Childhood in the Works of Silvina Ocampo and Alejandra Pizarnik. Woodbridge: Tamesis, 2003.

Matamoro, Blas. "La nena terrible". Oligarquía y literatura. Buenos Aires: Ed. del Sol, 1975. 193-221.

Molloy, Silvia. "Simplicidad inquietante en los relatos de Silvina Ocampo". Lexis 2/2 (1978): 241-251.

Moser, Walter. "Mélancolie et nostalgie: affects de la Spätzeit". Études Littéraires 31/2 (1999): 83-103.

Ocampo, Silvina. Cuentos completos. 2 vols. Buenos Aires: Emecé, 1999

Ocampo, Victoria. "Viaje olvidado". Sur 35 (1937): 119-120.

Page, Joanna. "Espacio privado y significación política en el cine de Lucrecia Martel". El cine argentino de hoy: entre el arte y la política. Viviana Rangil, ed. Buenos Aires: Editorial Biblos, 2007. 157-168.

Pezzoni, Enrique. "Silvina Ocampo: orden fantástico, orden social". El texto y sus voces. Buenos Aires: Editorial Sudamérica, 1986. 187-216.

Piret, Pierre. Présentation. Ginette Michaux, De Sophocle à Proust, de Nerval à Boulgakov: essaide psychanalyse lacanienne. Ramonville-Saint-Agne: Erès, 2008, coll. "Psychanalyse et écriture". 7-20.

Pizarnik, Alejandra. Prosa completa. Ana Becciu, ed. Ana Nuño, prol. Buenos Aires: Editorial Sudamericana, 2008.

Podlubne, Judith. "Juego de escondite: la narración de la infancia en Viaje olvidado de Silvina Ocampo". Boletín del Centro de Estudios de Teoría y Crítica Literaria 7 (1999): 88-103.

Schiesari, Juliana. The Gendering of Melancholia: Feminism, Psychoanalysis, and the Symbolics of Loss in Renaissance Literature. Ithaca: Cornell UP, 1992.

Zapata, Mónica. "Entre niños y adultos, entre risa y horror: dos cuentos de Silvina Ocampo". Le Fantastique argentin. Silvina Ocampo, Julio Cortázar. América, Cahiers du CRICCAL 17 (Paris: Presses de la Sorbonne Nouvelle, 1997): 345-361.

Revista Iberoamericana, Vol. LXXXII, Núm. 254, Enero-Marzo 2016, 71-89 
